\title{
SPIROERGOMETRIC AND TELEMETRIC INVESTIGATIONS DURING THE XXI INTERNATIONAL STOKE MANDEVILLE GAMES 1972 IN HEIDELBERG
}

\author{
By K.-D. Hüllemann, M. List, D. Matthes, G. Wiese and D. Zika \\ The Heidelberg University Medical School (Ludolf-Krehl-Klinik) II Institute and Depart- \\ ment for General Clinical Medicine (Director: Professor Dr. P. Christian)
}

Abstract. This paper deals with spiroergometric and telemetric studies which were carried out on Ioo paraplegic athletes during the XXI International Stoke Mandeville Games, 1972 in Heidelberg.

IN the literature (Guttmann, I956; Jung, Gottheiner \& Brunner, I97I; Rolf \& Witt, I972; Schiile, I972) there is little data on the cardiopulmonary efficiency of paralysed persons. Circulatory regulation was measured spirometrically in handicapped subjects for the first time in 1968 during the International Stoke Mandeville Games in Israel (Jung, Gottheiner \& Brunner, I97I). The present study was suggested by the National Olympic Stoke Mandeville Committee. The preparations had to be completed within five months.

\section{METHODS}

I. The Problem. To determine the cardiovascular and pulmonary efficiency in different classes of disability and various kinds of sport. Regulation of circulation during training and competition.

2. Investigative Procedure. Ergospirometry and exercise electrocardiography with a triangular exercise test (Cherchi, I968). Long-term ECG tape recording (Hüllemann, I973) and ECG telemetry (Hüllemann \& Mayer, I97I; Hüllemann, I973; Hüllemann et al., 1974).

3. Documentation and Statistics. Data-recording system appropriate for electronic data processing (Hüllemann, I970; Hüllemann et al., I97I; Hüllemann et al., 1972). Storage and evaluation of the data was carried out at the Documentation, Information and Statistics Institute at the German Cancer Research Centre, Heidelberg (Director, Prof. Dr. G. Wagner).

4. Investigating Personnel. Twelve persons: five doctors, two medical students, two bioengineers, one medical laboratory technician.

5. Apparatus. Spiroergometric measurement unit according to the 'open system'. Two telemetry systems, one of which had six transmitters. Long-term ECG recorder with six cassettes. Digital reading of heart rate. Two-track 
TABLE I

Number of TS in the disability classes and in the events. Weight-lifting (Wt.), basketball (B.b), ball/discus/javelin (B.D.J.), archery, wheelchair dash and slalom (D.S.), (a) men, (b) women, (c) all the TS in the two investigation procedures spiroergometry/telemetry and in the various events

\begin{tabular}{|c|c|c|c|c|c|c|c|c|c|c|c|}
\hline \multicolumn{5}{|c|}{ Spiroergometry } & \multicolumn{7}{|c|}{ Telemetry } \\
\hline Class & Wt. & B.b. & B.D.J. & $\Sigma$ & B.D.J. & Archery & D.S. & Swimming & Other & $\Sigma$ & $\Sigma \Sigma$ \\
\hline \multicolumn{12}{|c|}{ (a) Men } \\
\hline II & 4 & - & - & 4 & - & - & I & I & $\ldots$ & 2 & 6 \\
\hline III & 15 & - & I & 16 & 3 & 3 & 7 & - & 2 & 15 & $3^{I}$ \\
\hline IV & 9 & $\mathbf{I}$ & 3 & I3 & 2 & 5 & 6 & - & 3 & I6 & 29 \\
\hline V & 7 & 2 & I & IO & - & I & 2 & - & - & 3 & I3 \\
\hline VI & 4 & $\mathbf{I}$ & - & 5 & - & - & 一 & I & - & 2 & 7 \\
\hline$\Sigma$ & 39 & 4 & 5 & 48 & 6 & 9 & I6 & 2 & 5 & 38 & 86 \\
\hline
\end{tabular}

(b) Women

\begin{tabular}{|c|c|c|c|c|c|c|c|c|c|c|c|}
\hline $\begin{array}{l}\text { Ib } \\
\text { II } \\
\text { III } \\
\text { IV }\end{array}$ & $\begin{array}{l}- \\
- \\
-\end{array}$ & $\begin{array}{l}- \\
-\end{array}$ & $\begin{array}{c}\text { I } \\
\text { I }\end{array}$ & $\frac{\bar{I}}{I}$ & $\begin{array}{l}2 \\
\text { I } \\
\text { I } \\
\end{array}$ & - & $\begin{array}{l}\text { I } \\
\text { I } \\
\mathbf{2} \\
\end{array}$ & $\overline{-}$ & $\begin{array}{r}\mathbf{I} \\
\mathbf{I} \\
\end{array}$ & $\begin{array}{r}4 \\
3 \\
5 \\
\end{array}$ & $\begin{array}{l}4 \\
4 \\
5 \\
I\end{array}$ \\
\hline$\Sigma$ & 一 & - & 2 & 2 & 4 & - & 4 & I & 3 & 12 & 14 \\
\hline \multicolumn{12}{|c|}{ (c) Men and women } \\
\hline & 39 & 4 & 7 & 50 & IO & 9 & 20 & 3 & 8 & 50 & 100 \\
\hline
\end{tabular}

stereo magnetic tape unit for simultaneous recording of ECG and verbal information. Sphygmomanometer. Two radiotelephones. Three pocket cassette recorders. Three one-channel electrocardiographs. Underwater arrangement for telemetry. Out-patient kit with medicines for emergencies, intubation set and a resuscitation mask.

The test subjects (TS) were selected on the basis of their availability. The investigators were in direct contact with the athletes and their coaches. Those approached showed themselves cooperative. Major organisational difficulties with the TS gave rise to a rush and other psychological problems before the competition. A great deal of time and staff were required to meet simple human needs such as transport to and from meals and locating the toilet. The athletes lost interest in the study by the final days of the Games.

There were varying numbers of subjects in the individual kinds of sport and classes of disability (Table I). 


\section{TABLE II}

Heart rate $f_{h}$ (beats/min.) in the different kinds of sport and classes of bodily disabilities in men $(a)$ and women $(b)$. Resting $=$ lowest heart rate registered in the observation period of varying length. Exercise $=$ maximum heart rate during sporting activity. $n=$ no. of TS. $\bar{x} / x=$ average or single value. $s=$ standard deviation. $\min . / \max .=$ minimum value $/$ maximum value. B.D.J. $=$ ball, discus, javelin

(a)

\begin{tabular}{|c|c|c|c|c|c|c|c|c|}
\hline \multicolumn{6}{|c|}{$f_{h}$-Resting } & \multicolumn{3}{|c|}{$f_{h}$-Exercise } \\
\hline Kind of sport & Class & $n$ & $\bar{x} / x$ & $s$ & $\min . / \max$. & $\bar{x} / x$ & $s$ & $\min . / \max$. \\
\hline \multirow[t]{4}{*}{ Archery } & III & 3 & 98 & I2 & $85 /$ I IO & I 23 & I4 & $100 / 140$ \\
\hline & IV & 5 & 108 & I7 & $87 / 130$ & I3I & IO & II $2 / 185$ \\
\hline & V & I & I 20 & & & I 20 & & \\
\hline & & 9 & 109 & IO & & I27 & 5 & \\
\hline \multirow{5}{*}{$\begin{array}{l}\text { Wheelchair dash and } \\
\text { slalom }\end{array}$} & II & I & I09 & & & I90 & & \\
\hline & III & 7 & 92 & 4 & $75 / 110$ & I 75 & I I & I45/I 85 \\
\hline & IV & 6 & 97 & 2 & $77 / 120$ & I87 & 7 & $190 / 205$ \\
\hline & V & 2 & 87 & & $85 / 89$ & I90 & & I87/I92 \\
\hline & & I6 & 95 & IO & & I85 & 6 & \\
\hline \multirow[t]{4}{*}{ B.D.J. } & III & 3 & 102 & 19 & $65 / 125$ & I2I & I6 & IIO/I40 \\
\hline & IV & 2 & 83 & & $8 \mathrm{I} / 85$ & I07 & & $105 / 110$ \\
\hline & VI & I & 72 & & & 87 & & \\
\hline & & 6 & 85 & I 2 & & 105 & I4 & \\
\hline \multirow[t]{2}{*}{ Swimming } & II & I & 125 & & & 192 & & \\
\hline & VI & I & 105 & & & 180 & & \\
\hline
\end{tabular}

(b)

\begin{tabular}{|c|c|c|c|c|c|c|c|c|}
\hline Archery & III & 2 & 103 & & $102 / 105$ & I I 4 & & $99 / 130$ \\
\hline \multirow[t]{2}{*}{$\begin{array}{l}\text { Wheelchair dash and } \\
\text { slalom }\end{array}$} & $\begin{array}{l}\text { Ib } \\
\text { II } \\
\text { III }\end{array}$ & $\begin{array}{l}\text { I } \\
\text { I } \\
2\end{array}$ & $\begin{array}{r}109 \\
93 \\
125\end{array}$ & & & $\begin{array}{l}202 \\
185 \\
190\end{array}$ & & \\
\hline & & 4 & 109 & 16 & & 192 & 8 & \\
\hline \multirow[t]{2}{*}{ B.D.J. } & $\begin{array}{l}\text { Ib } \\
\text { II } \\
\text { III }\end{array}$ & $\begin{array}{l}2 \\
\text { I } \\
\text { I }\end{array}$ & $\begin{array}{l}74 \\
90 \\
90\end{array}$ & & $67 / 82$ & $\begin{array}{l}\text { I I } 2 \\
\text { I } 28 \\
\text { I } 30\end{array}$ & & $105 / 120$ \\
\hline & & 4 & 82 & IO & & I 20 & I I & \\
\hline Swimming & III & I & I I 5 & & & I 80 & & \\
\hline
\end{tabular}




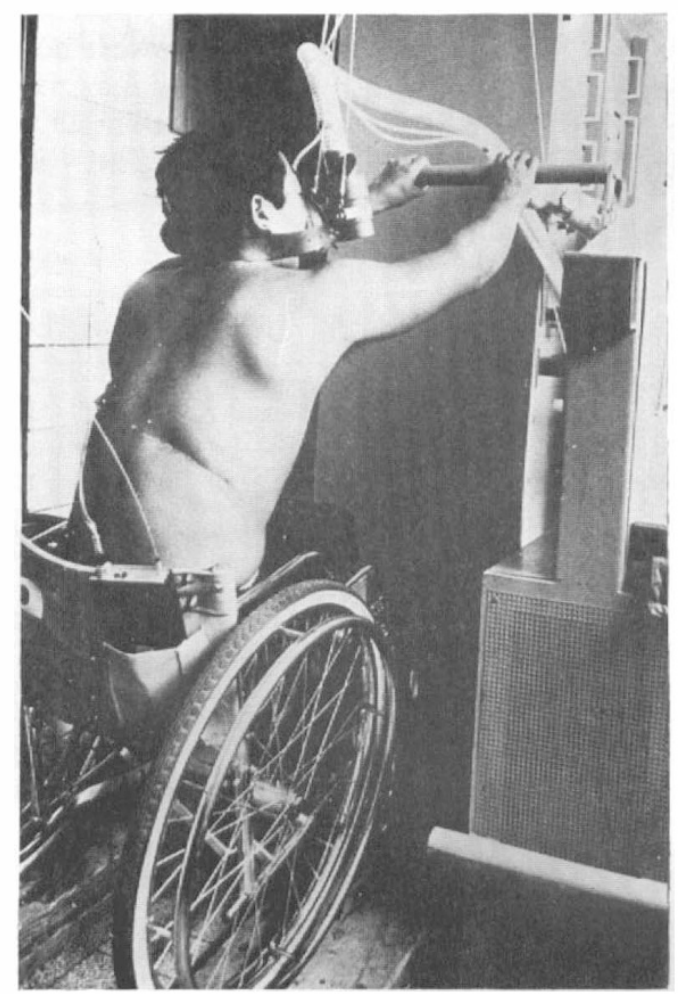

FIG. I

Spiroergometric measurement unit.

Of the 50 spiroergometric measurements, the largest group was that of the weight-lifters with 39 subjects. They had to produce the results of a circulatory investigation (at least an ECG) in order to get a starting permit. Because of this one-sided loading of the investigative capacity, only 12 further athletes were given an examination at the Games, two of them being women.

The frequency distribution in the 50 telemetry and recording studies (Table II $a$ and $b$ ) is largely attributable to the technical conditions.

The ratio of the crankhandle movement had to be reduced for the ergometric exercise position. This modification was taken into account in the work calculation. There were further technical difficulties due to differences in the height of the different types of wheelchair and severe wobbling of the wheelchairs with rubber wheels. The gain in time and the more 'true-to-life' conditions attained by the TS in their own wheelchairs (fig. I) had to be purchased with a non-optimal degree of effectiveness. 


\section{TABLE III}

Number of TS and number of participants of the various nationalities

\begin{tabular}{|c|c|c|}
\hline Nation & Participants & TS \\
\hline Australia & 37 & 3 \\
\hline Belgium & 31 & 4 \\
\hline Brazil & 20 & I \\
\hline FRG & 100 & 22 \\
\hline CSSR & 24 & IO \\
\hline Denmark & 28 & I \\
\hline Finland & 28 & 3 \\
\hline France & 90 & 4 \\
\hline United Kingdom & 94 & 7 \\
\hline India & 15 & I \\
\hline Jamaica & 24 & I \\
\hline Japan & 34 & 5 \\
\hline Yugoslavia & 29 & 6 \\
\hline Malaysia & 4 & 3 \\
\hline Norway & 40 & 3 \\
\hline Poland & 27 & 3 \\
\hline Switzerland & 47 & I4 \\
\hline Hungary & 7 & I \\
\hline U.S.A. & 83 & 8 \\
\hline Nations & 767 & 100 \\
\hline
\end{tabular}

Total of 44 nations. Total of I35 I participants

\section{RESULTS AND DISCUSSION}

A total of 100 participants from I9 nations were investigated (Table III).

I. Spiroergometry. Vital Capacity (VC) and Maximal Expiratory Flow Rate $(M E F R)$. The VC increases from $3913 \mathrm{ml}$. in disability class II to $4858 \mathrm{ml}$. in disability class V (Table IV). The MEFR shows the same tendency to rise within the disability classes. The increase of the MEFR from disability class II to III is statistically significant $(\mathrm{P}<0.02)$.

Efficiencies. The rise in the maximum work of 74 watts in disability class II to 127 watts in disability class VI (Table V) was not statistically significant. However, if one compares the total work expressed as the sum of the watts expended during the whole of the loading phase, a statistically significant $(P<0.02)$ increase in working capacity with decrease in the degree of disability is demonstrable (Table V, fig. 2).

Heart Rate. Under resting conditions the heart rate was $87 \pm 13$ beats per minute; in maximum loading the heart rate reached $153 \pm 18$ beats per minute. If 


\section{TABLE IV}

Average values and standard deviation of $\mathrm{VC}$ and MEFR of male disabled athletes

\begin{tabular}{|c|c|c|c|}
\hline $\begin{array}{c}\text { Disability } \\
\text { class }\end{array}$ & Number & \multicolumn{1}{|c|}{ VC } & \multicolumn{1}{|c|}{ MEFR } \\
\hline II & 4 & $3913 \pm 773$ & $5 \cdot 97 \pm \mathrm{I} \cdot 63$ \\
III & I5 & $4352 \pm \mathrm{I054}$ & $8 \cdot 2 \mathrm{I} \pm \mathrm{I} \cdot 35$ \\
IV & I2 & $4454 \pm 853$ & $8 \cdot \mathrm{I} 6 \pm \mathrm{I} \cdot 97$ \\
V & 9 & $4858 \pm 977$ & $8 \cdot 26 \pm 2 \cdot \mathrm{I} 3$ \\
VI & 5 & $4640 \pm 509$ & $8 \cdot 86 \pm \mathrm{I} \cdot 86$ \\
\hline Sum & 45 & $4449 \pm 939$ & $8 \cdot 08 \pm \mathrm{I} \cdot 83$ \\
\hline
\end{tabular}

\section{TABLE V}

Average values and standard deviation of the male disabled athletes

\begin{tabular}{|c|c|c|c|c|c|}
\hline $\begin{array}{l}\text { Disability } \\
\text { class }\end{array}$ & Number & $\begin{array}{c}\text { Age } \\
\text { (years) }\end{array}$ & $\begin{array}{l}\text { Weight } \\
\text { (kg.) }\end{array}$ & $\begin{array}{l}\text { Max. } \\
\text { loading } \\
\text { (watts) }\end{array}$ & $\begin{array}{l}\text { Total work } \\
\text { (watts) }\end{array}$ \\
\hline $\begin{array}{l}\text { II } \\
\text { III } \\
\text { IV } \\
\text { V } \\
\text { VI }\end{array}$ & $\begin{array}{r}4 \\
16 \\
13 \\
10 \\
5\end{array}$ & $\begin{array}{l}27 \cdot 0 \pm 5 \cdot 92 \\
30 \cdot 8 \pm 6 \cdot 27 \\
28 \cdot 8 \pm 8 \cdot 4 \\
29 \cdot 7 \pm 6 \cdot 5 \\
27 \cdot 8 \pm 5 \cdot 6\end{array}$ & $\begin{array}{l}59 \cdot 3 \pm 11 \cdot 5 \\
71 \cdot 1 \pm 20 \cdot 8 \\
63 \cdot 0 \pm 12 \cdot 0 \\
70 \cdot 2 \pm 14 \cdot 0 \\
77 \cdot 2 \pm 7 \cdot 9\end{array}$ & $\begin{array}{r}74 \pm 43 \\
104 \pm 27 \\
95 \pm 30 \\
\text { I1 } 3 \pm 32 \\
\text { I } 27 \pm 32\end{array}$ & $\begin{array}{l}285 \pm 169 \\
423 \pm 127 \\
384 \pm 127 \\
503 \pm 130 \\
522 \pm 105\end{array}$ \\
\hline Sum & 48 & $29 \cdot 4 \pm 6 \cdot 7$ & $68 \cdot 4 \pm I \cdot 6$ & $103 \pm 32$ & $430 \pm 142$ \\
\hline
\end{tabular}

the disability classes are compared with one another, there is practically no difference in the behaviour of the pulse frequency.

Blood Pressure. Systolic and diastolic blood pressure had approximately the same values in all the disability classes: at rest $\mathrm{I} 4 \mathrm{I} \pm \mathrm{I} 9 / 96 \pm 9 \mathrm{~mm}$. $\mathrm{Hg}$ and during maximum exercise $\mathrm{I} 65 \pm \mathrm{I} 0 / 93 \pm \mathrm{II} \mathrm{mm}$. $\mathrm{Hg}$.

Maximum Oxygen Uptake ( $\dot{V}_{\mathrm{O}_{2}}$ max.). The $\dot{V}_{\mathrm{O}_{2}}$ max. increases from $69 \mathrm{I} \mathrm{ml}$. (class II) to I 54I ml. (class VI) (Table VI). The maximum oxygen/pulse increases in a similar way. The difference for $\dot{V}_{\mathrm{O}_{2}} \max$. and $\dot{V}_{\mathrm{O}_{2}} \max . / f_{h}$ between classes II and VI are statistically significant $(\mathrm{P}<0.5)$.

Ventilation Equivalent. There were no consistent differences in the ventilation equivalent between the performance classes.

Electrocardiogram. No pathological changes were observed. 
Total work (watts)

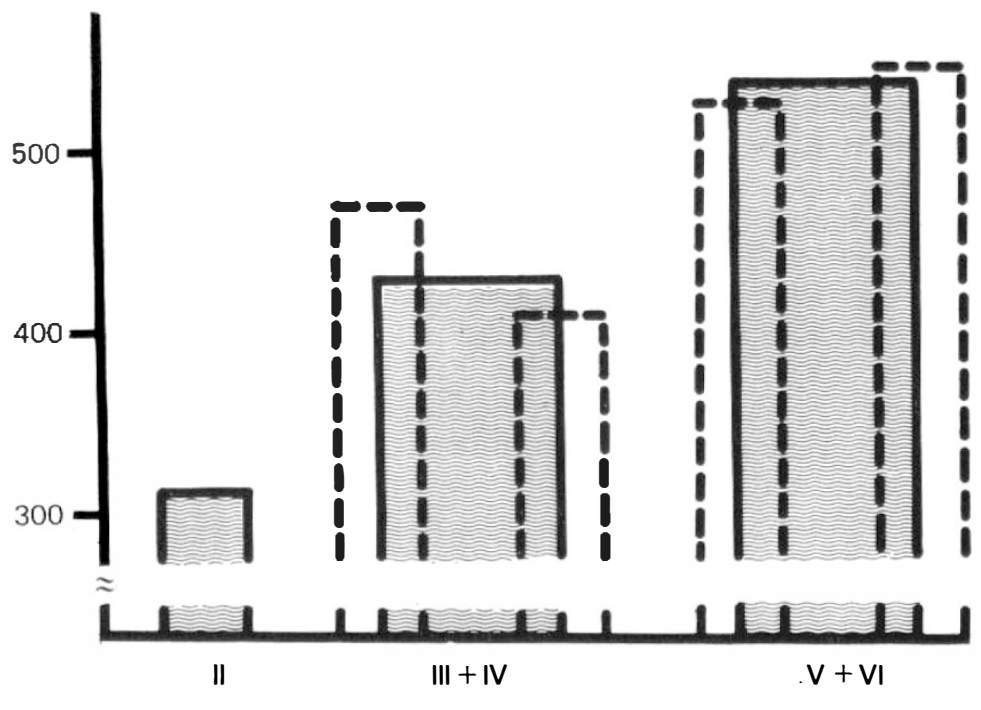

FIG. 2

Average values of total work (sum of watts) within the disability classes II-IV. The differences between the disability classes II, III + IV, and V+VI are significant $(P<0.02)$.

\section{TABLE VI}

Average values and standard deviation of the maximum values of oxygen uptake and oxygen/ pulse in disabled athletes

\begin{tabular}{|c|c|c|c|}
\hline $\begin{array}{c}\text { Disability } \\
\text { class }\end{array}$ & Number & $\begin{array}{c}\text { Max. } \\
\mathrm{O}_{2} \text { uptake } \\
\text { (ml.) }\end{array}$ & $\begin{array}{c}\text { Max. } \\
\mathrm{O}_{2} \text { pulse }\end{array}$ \\
\hline $\begin{array}{l}\text { II } \\
\text { III } \\
\text { IV } \\
\text { V } \\
\text { VI }\end{array}$ & $\begin{array}{r}4 \\
13 \\
10 \\
5 \\
4\end{array}$ & $\begin{array}{r}961 \pm 365 \\
1272 \pm 435 \\
1409 \pm 535 \\
1283 \pm 276 \\
1541 \pm 165\end{array}$ & $\begin{array}{l}6 \cdot 38 \pm 2 \cdot 26 \\
8 \cdot 25 \pm 2 \cdot 65 \\
9 \cdot 00 \pm 2 \cdot 70 \\
8 \cdot 75 \pm 2 \cdot 10 \\
9 \cdot 75 \pm 1 \cdot 04\end{array}$ \\
\hline Sum & 36 & $1302 \pm 436$ & $8 \cdot 48 \pm 2 \cdot 52$ \\
\hline
\end{tabular}

\section{DISCUSSION}

The VC of $4449 \pm 939 \mathrm{ml}$. found in the handicapped agree with the values determined by Jung et al. (1971), who found a VC of $4500 \mathrm{ml}$. in 24 paraplegic athletes. These values are substantially higher than those obtained by Voigt 
et al. (1968) in I3 non-trained male paraplegics (3000). According to Baldwin et al. (1948) VC values in comparable non-disabled subjects is $4480 \mathrm{ml}$. The values for our disabled subjects are 500 to $1000 \mathrm{ml}$. less than those given by Bühlmann and Scherrer (1973), which were 5000 to $5500 \mathrm{ml}$. If one takes into account that $\mathrm{VC}$ in a sitting position is ten per cent lower than when standing (Hollmann, 1972), then the difference from the non-disabled comparison collective is only slight. Within the disability classes the VC increases the lower the transverse lesion is located in the spinal cord. It can be assumed that these differences would also be statistically demonstrable with a larger sample of subjects. The MEFR lies within the normal range in disability classes III to IV (Fabel \& Hamm, I962). The significantly lower MEFR in disability class II is attributable to the localisation of the injury (ThI-Th5), in which only a part of the rump musculature can be innervated actively. With increasing possibility of activating the musculature, i.e. localisation of the transverse injury lower in the spinal cord, a larger total physical work (sum of watts) and maximum work (watts) can be achieved. Since their total work is the same, disability classes III and IV and also V and VI can be lumped together (fig. 2). The resting heart rate is $I 7$ beats higher than that stated by Jung et al. ( $70 \pm \mathrm{I} 4$ beats/min.). The difference may be attributable to the crankhandle's being moved at freewheel during the rest phase in the present study and to a higher level of mental excitation of the athletes due to the competition frequently impending on the same day. The maximum heart rate was $153 \pm$ I 8 beats per minute. Comparable non-disabled subjects have a heart rate almost 30 beats per minute lower at the same exercise if this was determined with foot crankhandle work in the lying position. According to Mellerovicz (1975) more oxygen, a larger minute volume and higher respiratory rate is necessary for the same physical performance with hand crankhandle work than in foot crankhandle work in the sitting or lying position. The effectiveness of the crankhandle work is substantially more unfavourable. This was also demonstrated by Jung et al. (I97I) in a group of sport students who showed 56 per cent less than maximal exercise when tested by crankhandle ergometry as compared to bicycle ergometry.

Despite different exercise within the disability classes, the maximum heart rate is almost the same. Maximum performance for individuals with differing degrees of disability entails almost the same psychophysical effort; 74 watts work is just as difficult to produce for disabled subjects of class II as is 127 watts work for subjects of class VI.

The values of the indirectly measured blood pressure (I4I \pm I9/96 \pm I $2 \mathrm{~mm}$. $\mathrm{Hg}$ ) at rest are markedly higher than the norm for elderly subjects (Meesmann et al., 1970). This elevation is to be viewed as a result of the generally larger arm size of the disabled, especially since the 32 TS trained either exclusively with weight-lifting or additionally with other kinds of sport. In four disabled subjects who engaged exclusively in light athletics, the blood pressure is markedly lower ( $136 \pm 10 / 89 \pm 10 \mathrm{~mm} \mathrm{Hg}$ ). Since the size of the upper arm was not measured, the blood-pressure values could not be corrected as suggested by Pickering (1969).

The increase of systolic blood pressure from $25 \mathrm{~mm}$. Hg with moderate work of $103 \pm 32$ watts is slight. As could be shown by Jung et al. (I97I), the comparatively lower increase in systolic pressure is not a characteristic of disabled athletes, but is attributable to the kind of exercise (crankhandle work in the sitting position).

The maximum increase in oxygen uptake ( $1302 \mathrm{ml}$.) is markedly less than 
the comparable value in the non-disabled, which was stated by Valentin et al. (I955) to be $3200 \mathrm{ml}$. with rotating crank work in the standing position. This $\dot{V}_{\mathrm{O}_{2}}$ max. of the disabled subjects relative to the comparison value was also depressed if one takes into account that exercise in a sitting position is associated with a lower uptake of oxygen (Mellerovicz \& Nowacki, I96I). Voigt et al. (I968) and Jung et al (I97I) also found a lowered maximum oxygen uptake in wheelchair patients. This results from the disabled musculature not carrying out any work.

The dynamic changes of the ventilation equivalent which were recorded indicated an economically favourable operation (Hollmann, I963, I972).

2. Telemetry. The highest pulse frequencies (more than 180 to 205 beats per minute) were reached in dashes and slaloms (Table VII, figs 3 and 4) and in

\section{TABLE VII}

Heart rate (beats/min.) in short-distance and slalom races. Above I4 men. In addition, the values of the Gold Medal winner in Slalom ( $\left.I^{\star}\right)$ are given. Below 4 women. Resting = lowest heart rate during the period of observation. Training, pre-start, competition $=$ maximum frequency. Pre-start $=$ directly before the starting shot

\begin{tabular}{|c|c|c|c|c|c|c|}
\hline$n$ & & $\begin{array}{c}\text { Age } \\
\text { (years) }\end{array}$ & Resting & Training & Pre-start & Competition \\
\hline I4 & $\begin{array}{l}\bar{x} \\
s \\
\text { min./max. }\end{array}$ & $\begin{array}{c}26 \\
6 \\
18 / 4 \mathrm{I}\end{array}$ & $\begin{array}{l}95 \\
10 \\
75 / 120\end{array}$ & $\begin{array}{l}\text { I59 } \\
\text { I5 } \\
\text { I } 35 / 180\end{array}$ & $\begin{array}{l}\text { I3I } \\
\text { I8 } \\
96 / \text { I } 70\end{array}$ & $\begin{array}{l}\text { I86 } \\
\text { IO } \\
\text { I60/205 }\end{array}$ \\
\hline$I^{\star}$ & & 23 & 95 & I 50 & I25 & I 82 \\
\hline 4 & $\begin{array}{l}\bar{x} \\
s \\
\text { min./max. }\end{array}$ & $\begin{array}{c}31 \\
3 \\
24 / 32\end{array}$ & $\begin{array}{l}104 \\
\text { I6 } \\
90 / 125\end{array}$ & -- & $\begin{array}{l}\text { I } 28 \\
\text { I2 } \\
\text { I I I / I } 40\end{array}$ & $\begin{array}{l}\text { I9I } \\
\text { IO } \\
\text { I } 82 / 202\end{array}$ \\
\hline
\end{tabular}

swimming (fig. 5). Weight-lifting also led to a comparable tachycardia (fig. 6). It was possible to record the ECG continuously during the crucial competition in which a 23-year-old sportsman won the Gold Medal in the slalom (Table VIII, fig. 7).

It was not possible to show an influence of sex and disability class on regulation of heart rate. Figure 4 shows the effect of age; the 4I-year-old-athlete $(a)$ has about 20 beats less than his 16 to 23 years younger opponents. On the other hand, the influence of psychogenic factors is clear. Even the start situation accelerated the pulse by 30 beats (Table VII). The peak heart rates in competition are on average 25 beats higher than in training (Table VII). During the prize-giving the heart rate of a 2 I-year-old gold-medal winner (female) rose from 95 to I20 at the time her name was called out. In a similar situation a I7-year-old athlete (also female) developed a $4:$ I extrasystole with an increase of heart rate from 82 to 93. This disturbance of rhythm could not be demonstrated in an exercise test 


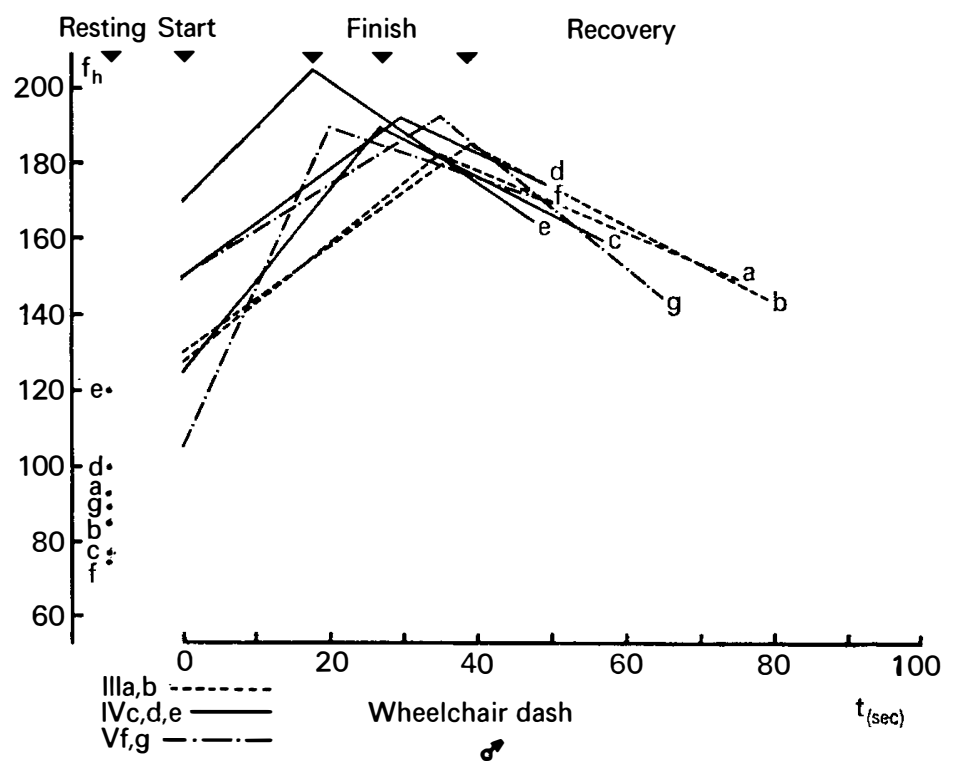

FIG. 3

Course of changes in heart rate during the men's dashes. Resting $=$ lowest value during the observation period (which varied in length). Start = directly before the starting shot. Finish $=$ situation in which the participants $a$ to $g$ pass the finishing line. The highest heart rate largely coincides with reaching the finish.

(4)

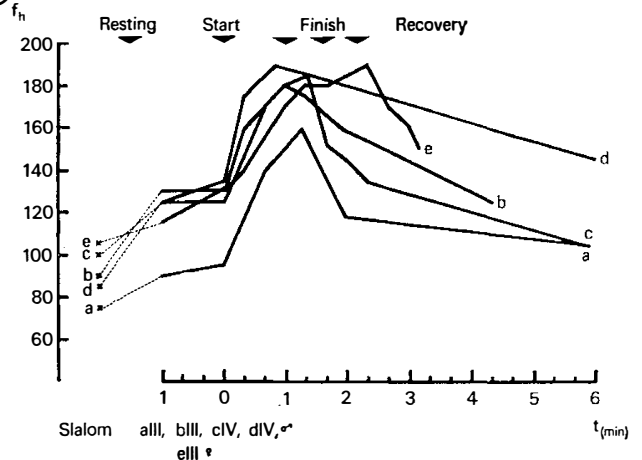

Fig. 4

Heart rate $f_{h}$ (beats/min.) during slalom competitive races. The values on the left (outside the abscissa) correspond to the lowest values of heart rate recorded during the observation period (which was of varying length). Finish = time interval in which all five participants pass the finishing line. $a=4 \mathrm{I}$ years. $b=22$ years, $c=25$ years. $d=23$ years; values measured during the Gold Medal competition. $e=3$ I-year-old woman. 


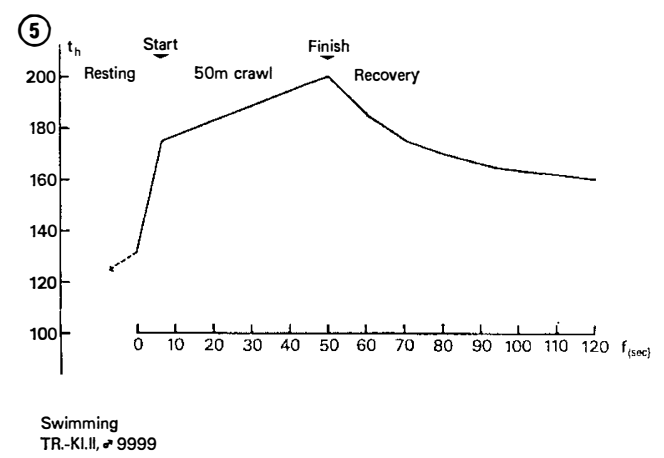

FIG. 5

Course of changes in heart rate during swimming training. Resting $=$ lowest heart rate during the period of observation.

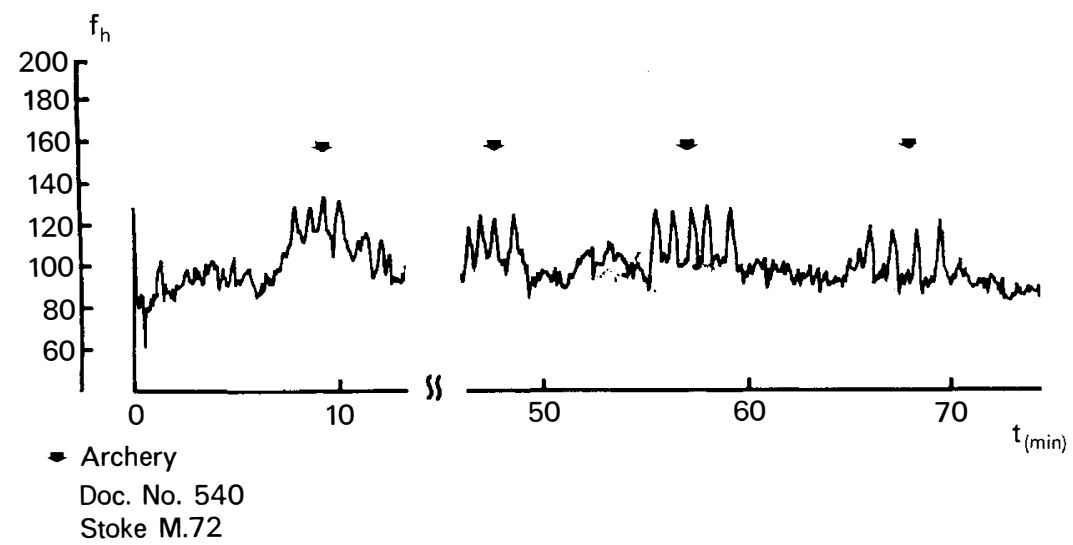

FIG. 6

Course of changes in heart rate during archery. The arrows mark a series of shots. The course of the pulse frequency from the 70th to the I20th minute corresponds to the curve shown.

with continuous ECG monitoring. During a Eurovision programme two weightlifters had tachycardias up to more than $\mathrm{I} 20$ beats/min. even at rest (fig. 8). Filming the situation or speaking to the TS accelerated the pulse rate by 20 beats. There were no pathological findings in any TS.

\section{DISCUSSION}

The peak values of heart rate reached by the wheelchair subjects are of the same order as those reached by healthy sportsmen in similar events (Bassan, 1967; Kastner et al., Vogler \& Glasing, 1970). The different strength of the circulatory reaction to largely static exercises with only very short dynamic intervals as 


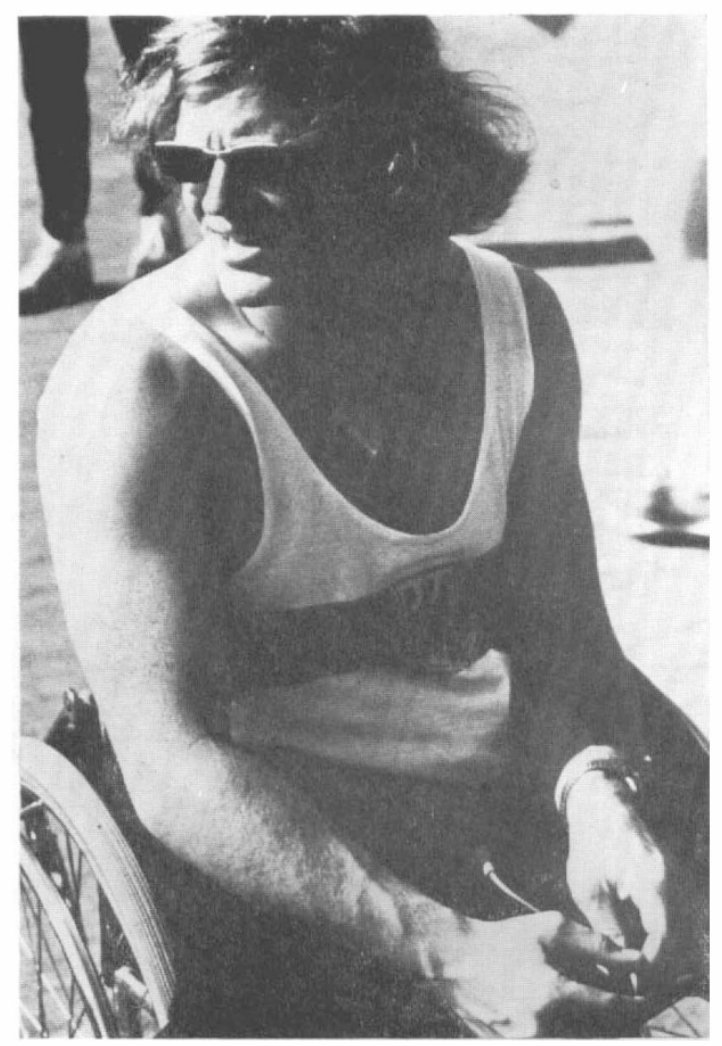

Fig. 7

Gold Medal winner in the slalom, 23-year-old medical student.

opposed to purely dynamic strenuous exercise is comparable with healthy subjects (Hollmann, I963, I972; Hollmann \& Heck, I97I).

A dependence of the acceleration of heart rate on sex and disability class could not be demonstrated. This is based (apart from the small sample number) on the fact that all the bodily activities studied are too short in duration for one to assume that the cardiovascular system is the factor limiting performance (Reindell et al., 1967; Mellerovicz, 1975). In the Olympic situation, the mental involvement illustrated above plays a particular role. The high peak frequencies of 200 were also reached in formula and touring car drivers (Hüllemann \& List, 1973); with the low level of bodily activity during the race, this is mainly due to the extreme mental tension. These motor racing drivers show a tachycardiac pre-start reaction like that of the disabled sportsmen. There is further agreement in the higher rise in heart rate during the competition compared to training. Disturbances of the heart rhythm such as appeared at the prize-giving occur similarly in television viewers during live transmissions of sports programmes (Hüllemann \& Mayes, I97I). 


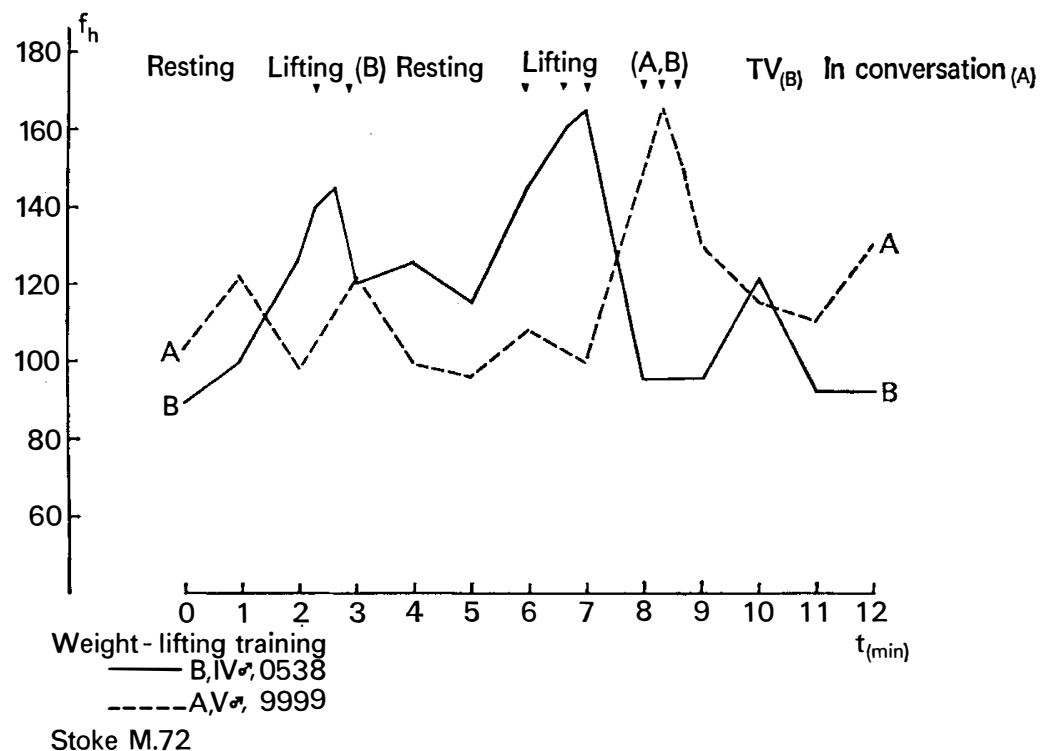

Fig. 8

Course of changes in heart rate of two weight-lifters during a Eurovision transmission. $\mathrm{TV}_{(\mathrm{B})}=$ television camera on subject $\mathrm{B}$. In conversation $(\mathrm{A})=(\mathrm{A})$ talks to the doctor.

\section{SUMMARY}

Spiroergometric and telemetric investigations were carried out on Ioo paralysed athletes during the XXI International Stoke Mandeville Games in Heidelberg, 1972. The technical and organisational difficulties in carrying out these measurements were engendered by the disabilities of subjects. The maximum oxygen uptake observed and the oxygen pulse were lower than in non-disabled persons. There were no differences in the peak heart rates (I80-200 beats/min.) as compared with non-disabled athletes during particular competition situations. Sports characterised by quickness, dexterity and strength are not able to train the cardiopulmonary system substantially. Swimming is recommended as beneficial.

Psychological and training physiological considerations suggest that longdistance wheelchair races should be adopted as a Stoke Mandeville event.

\section{RÉSUMÉ}

Les investigations spiro-ergométriques et télémétriques ont été effectuées chez 100 athlètes paralysés pendant les XXIè Jeux Internationaux de Stoke Mandeville qui se sont tenus à Heidelberg en 1972. L'invalidité des sujets a occasionné des difficultés techniques et d'organisation pour étudier les paramètres. La consommation maximale d'oxygène observée ainsi que le pouls d'oxygène était plus bas que chez les personnes non paralysées. Il n'y avait pas de différence en ce qui concerne le rythme cardiaque maximal, (I80 à 200/ minute) en comparaison avec les athlètes non handicapés pendant les situations particulières. de compétition. Les sports caractérisés par la rapidité, la dextérité et la force ne sont pas capables d'entraîner le système cardio-pulmonaire de façon substantielle. La natation est recommandée comme étant bénéfique. Les considérations psychologiques et les aspects $13 / 2-D$ 
physiologiques de l'entraîenment suggerent que les courses en fauteuil roulant sur de longues distances devraient être adoptées dans les compétitions des Jeux de Stoke Mandeville.

\section{ZUSAMMENFASSUNG}

Spiroergometrische und telemetrische Untersuchungen wurden bei Ioo gelähmten Athleten während der XXI. Internationalen Stoke Mandeville Spiele in Heidelberg, 1972 ausgeführt. Technische und organisatorische Schwierigkeiten während der Messungen waren bedingt durch die Disabilität der Untersuchten. Der maximale Sauerstoffverbrauch und der Oxygenpuls war geringer als bei Nichtgelähmten. Kein Unterschied wurde im der maximalen Herzrate (I80-200 per Minute) im Vergleich mit nicht-gelähmten Athleten während speziellen Wettkampf-Situationen gefunden. Sportarten charakteristisch für Schnelligkeit, Geschicklichkeit und Kraft sind nicht geeignet, das kardio-pulmonale System erheblich zu trainieren. Schwimmen wird als vorteilhaft empfohlen. Aus psychologischen und training physiologischen Erwägungen werden Lang-Strecken Rollstuhl-Wettfahren für die Stoke Mandeville Spiele emphfohlen.

\section{REFERENCES}

Baldwin, E. F., Cournard, A. \& Richards, D. W. (1948). Medicine (Baltimore), 25, 243.

BASSAN, L. (1967). Simultane radiotelemetrische Untersuchungen der Herzfrequenz bei Rudern unter Wett-kampfbedingungen. Theorie und Praxis der Körperkultur. H., $3 / 4,25 \mathrm{I}$.

BüHLManN, A. A. \& ScherRer, M. (1973). Schweiz. med. Wschr. 103, 660-668.

CHERCHI, A. (1968). A synthetic triangular exercise test. In Ergometry in Cardiology, Eds. Denolin, H., König, K., Messin, R., Degre, S. Böhringer, Mannheim GmbH.

FABEL, H. \& HAMM, J. (1962). Dtsch. med. Wschr. 87, 236I-2364.

GutTMANN, L. (1956). Dtsch. Z. Nervenheilkunde, 175, I73-190.

HollmanN, W. (1963). Höchst- und Dauerleistungsfähigkeit des Sportlers. Barth, München.

HollanN, W. (1972). Lungenfunktion, Atmung und Stoffwechsel im Sport. In Zentrale Themen der Sportmedizin, Ed. Hollmann, W. Springer, Berlin-Heidelberg-New York.

HollmanN, W. \& HeCK, H. H. (I97I). Herzleistungsfähigkeit und Sport. Ärztl. Fortbild. $19,62$.

HÜllEMANN, K.-D. (1970). Ein Datenerfassungsbogen fur die Leistungsmedizin. Meth. Inform. Med. 9, 23 I-237.

HÜLLEMANN, K.-D. (I973). Kreislaufuntersuchungen während der Olympiade der Gelähmten 1972. In Wege zur Chancengleichheit der Behinderten, Kongressbericht dtsch. Vereiningung Rehabil. Behinderter, Heidelberg, 195-197.

HüllemanN, K.-D., BRINkHUS, H, \& StaHLHEBER, R. (I97I). Ein Datenerfassungsbogen für die Leistungsmedizin. Second communication: Lungenfunktion, Ärztl. Formbericht. Meth. Inform. Med. 10, 228-232.

HüllemanN, K.-D., Greulich, B. \& List, M. (1972), Ein Datenerfassungsbogen für die Leistungsmedizin. Third Communication: Verwendete Schlüssel, Dateiführung, Fehlerprüfung, Auswertung. Meth. Inform. Med. 11, 186-190.

HÜllemanN, K.-D. \& LIST, M. (1973). Fortlaufende EKG-Aufzeichung bei Autorennfahrern. Med. Welt, 24, 1360-1363.

HüllemanN, K.-D., Matthes, D., Wiese, G. \& List, M. (1974). Kardiopulmonale Leistungsfähigkeit von Versehrtensportlern. Münch. Med. Wschr. 116, 49 I-494.

HÜllemanN, K.-D. \& MaYeR, H. (I97I). EKG-Telemetrie. Technik und praktische Anwendung. Münch. Med. Wschr. 112, 2 III-2II8.

HÜllemanN, K.-D., Wiese, G., List, M., Matthes, D. \& ZikA, D. (I974). Olympiade der Gelähmten 1972. Durchführbarkeit von Kreislaufuntersuchungen. Rehabilitation, 13, 30-36.

HüllemanN, K.-D., Zika, D., Matthes, D., Wiese, G. \& List, M. (I974). Fortlaufende EKG-Aufzeichungen während der Olympiade der Gelähmten 1972. Med. Techn. 94, I38-I 4 I.

Jung, K., GotTheiner, D. \& BRUnneR, D. (I97I). Kombinierte spiroergometrische Untersuchung bei Versehrtensportlern. Physikal. Med. 2, I25-I4I. 
Kastner, K., Heck, H., Schmücker, B. \& Hollmann, W. (1970). Pulsfrequenzregistrierung bei Sportler verschiedener Disziplinen. In Biotelemetrie, Eds. Demling, L. und Bachmann, K. Thieme, Stuttgart.

MatThes, D., HÜLlEMANN, K.-D. \& WIESE, G. (I973). Methoden der Blutdrucktelemetrie. Med. Techn. 93, I29-131.

Mellerowicz, H. (I975). Ergometrie. Urban \& Schwarzenberg, München-Berlin-Wien.

Mellerowicz, H. \& NowaCkI, P. (I96I). Z. Kreisl.-Forsch. 50, IOO2.

PICKERING, G. (1969). High Blood Pressure, 2 Edition. J. \& A. Churchill Ltd., London.

ReINDELl, H., KöNIG, K. \& RossKamm, H. (1967). Funktionsdiagnostik des gesunden und kranken Herzens. Thieme, Stuttgart.

Rolf, G. \& WitT, H. (1972). Der klinische Sport in der Rehabilitation Querschnittsgelahmter. Kohlhammer, Stuttgart-Berlin-Köln-Mainz.

SCHÜLE, K. (I972). Möglichkeiten und Grenzen des Sports mit Spinalgeschädigten. Med. Welt, 23, I I23- I 126.

Sturm, A. (1970). Arterielle Hochdruckerkrankungen. Pathogenese, Diagnose und Therapie des arteriellen Hochdrucks. Steinkopff, Darmstadt.

Valentin, H., Venrath, H., Balodimos, J. \& Giovannelli, G. (1955). Z. Kreisl.-Forsch. 44, $770-785$.

VogLER, G. \& GLASING, D. (1970). Verhalten der Herzfrequenz beim Kunstturnentraining. In Biotelemetrie, Eds. Demling, L., Bachmann, K. Thieme, Stuttgart.

Voigt, E. D., Berendes, B. \& Hildebrand, G. (1968). Arbeitsmed., Sozialmed. Arbeitshyg. 5, I35-I 38. 